2020 Global Marketing Conference at Seoul Proceedings: 639-644 (November 2020) https://doi.org/10.15444/GMC2020.05.06.03

\title{
TOURIST-HOTEL RELATIONSHIP: THE ROLE OF CUSTOMER EXPERIENCE AND BRAND AUTHENTICITY
}

\author{
Filipa Rosado-Pinto, Instituto Universitá rio de Lisboa (ISCTE-IUL), Business \\ Research Unit (BRU-IUL), Lisboa, Portugal ${ }^{1}$ \\ Sandra Maria Correia Loureiro, Instituto Universitá rio de Lisboa (ISCTE-IUL), \\ Business Research Unit (BRU-IUL), Lisboa, Portugal ${ }^{2}$ \\ Ricardo Godinho Bilro, Instituto Universitá rio de Lisboa (ISCTE-IUL), Business \\ Research Unit (BRU-IUL), Lisboa, Portugal ${ }^{3}$
}

\begin{abstract}
The demand for authenticity has been growing in the contemporary world and in consumers' lives (Fine, 2003; Grayson \& Martinec, 2004). According to Grayson and Martinec (2014), the quest for authenticity has existed for many years. However, today it is reflected in the purchase of several market offerings. In a time of intense competition, it is difficult for companies to differentiate their products (goods or services) and authenticity can, indeed, act as an important element of differentiation (Gilmore \& Pine, 2007). Despite the relevance of the term, research about authenticity has been very fragmented and different definitions can be found in the literature (Beverland \& Farrelly, 2010; Grayson \& Martinec, 2004). In any case, some level of agreement can be identified as authenticity is many times associated with being genuine, real and/or true (Beverland \& Farrelly, 2010). When the concept is applied to objects like, for instance, brands, the notion of brand authenticity emerges (Fritz, Schoenmueller, \& Bruhn, 2017).

The relevance of authenticity in modern times has led several scholars to study it in different areas of knowledge like, for example, sociology, anthropology, psychology and philosophy (Bruhn, Schoenmüller, Schäfer, \& Heinrich, 2012; Fritz et al., 2017). In the marketing field, the topic has been described as "one of the cornerstones of contemporary marketing" (Brown, Kozinets, \& Sherry, 2003, p. 21). Despite the importance of the topic and the research that has already been developed, Bruhn et al. (2012) state that the study of authenticity is still in its infancy. Adding to this, Fritz et al. (2017) argue that it would be interesting to have more insights about authenticity within the service context and other studies refer the importance of exploring the concept of authenticity/ brand authenticity in different industries or segments (e.g. Ilicic \& Webster, 2014; Mody \& Hanks, 2019; Napoli, Dickinson-Delaporte, \& Beverland, 2016; Spiggle, Nguyen, \& Caravella, 2012). In the case of hospitality and tourism, authenticity has been playing an important role. However, it is stated that "even though authenticity has not been ignored in the hospitality and tourism research, it is still understudied in the hotel sector" (Manthiou, Kang, Hyun, \& Fu, 2018, p. 39).
\end{abstract}

Fritz et al. (2017) argue that although there is a trend of growing research regarding the study of the antecedents and consequences of brand authenticity, there is still a research

\footnotetext{
filipa.rosado.pinto@iscte-iul.pt

sandramloureiro@netcabo.pt

3 bilro.ricardo@gmail.com
} 
gap concerning this topic. Fritz et al. (2017), not only highlight the need to have a deeper understanding of the antecedents and consequences of brand authenticity, but they also point out that it is important to identify different brand contexts where the perception of authenticity can vary. Other studies refer that deeper research about the relationship of brand authenticity and other related constructs is also required (e.g. Morhart, Malär, Guèvremont, Girardin, \& Grohmann, 2015; Moulard, Raggio, \& Folse, 2016).

Another very important concept, within the marketing field, which is considered a research challenge for the next years, is customer experience (Lemon \& Verhoef, 2016). Pine and Gilmore (1998) were some of the first scholars who have pointed out the importance of customer experience, considering that "while prior economic offeringscommodities, goods and services- are external to the buyer, experiences are inherently personal, existing only in the mind of an individual who has been engaged on an emotional, physical, intellectual or even spiritual level" (Pine \& Gilmore, 1998, p. 99). Pine and Gilmore (1998) suggest that this concept is multidimensional and that there are four "realms" of an experience: educational, entertainment, esthetic and escapist. According to the authors, experiences that people think of as entertainment are those where customers are more passive than active (e.g. watching Tv or attending to a concert). In contrast, educational experiences (for instance, attending to a class), tend to involve more the participants. In the case of escapist experiences, they require more customer immersion. These experiences can teach something, like the educational experiences or amuse, like more entertaining experiences. This is the case, for instance, of acting in a play. Finally, an experience that has a more esthetic component is characterized by the customer/participant being immersed in an activity but having a small effect on it (e.g. a tourist enjoying a view).

Several definitions of the construct can also be found in the literature. In the case of Lemon and Verhoef (2016), customer experience has been defined as "a multidimensional construct focusing on a customer's cognitive, emotional, behavioral, sensorial, and social responses to a firm's offerings during the customer's entire purchase journey" (Lemon \& Verhoef, 2016, p. 71).

Some knowledge gaps regarding the concept of customer experience have been highlighted. Firstly, Lemon and Verhoef (2016) state that it would be important to have a deeper understanding about the outcomes of customer experience, like, for instance, the long-term loyalty effects of the customer journey and the immediate purchase consequences. Secondly, although the importance of experience in hospitality and tourism is recognized, having more empirical evidence about the subject, applied to the hotel context, would be important to understand the topic in this specific context (Walls, 2013).

Therefore, the objectives of this study are: i) to have a deeper knowledge about brand authenticity in the hospitality context, ii) to explore brand authenticity's antecedents and outcomes, in the hospitality context, iii) to study the outcomes of customer experience, in the hospitality context.

Within the marketing field, the concept of brand authenticity has been defined in different ways, for example, "as a subjective evaluation of genuineness ascribed to a brand by consumers" (Napoli, Dickinson, Beverland, \& Farrelly, 2014, p. 1091). 
Another perspective considers that "(1) Authenticity in the context of brands deals with the authenticity of market offerings (objects and services) in contrast to the authenticity of human beings; (2) Brand authenticity is based on the evaluations of individuals rather than being solely related to the inherent attributes of the brand (for references on this topic cf. Beverland and Farrelly 2010); (3) Brand authenticity corresponds to a variety of attributes since there is no unique definition of the authenticity concept, particularly in the branding context" (Bruhn et al., 2012, p. 567). A third perspective describes an authentic brand as "one that is perceived by consumers as having a clear philosophy it lives by; one with a sense of what it stands for; a brand that lives up to its promise" (Dwivedi \& McDonald, 2018, p. 1391).

Despite the different perspectives and definitions of the topic, after performing the literature review, it is possible to state that the majority of the works assume a multidimensional perspective of the construct. For instance, Bruhn et al. (2012) develop a scale to measure consumers' perceived brand authenticity with four dimensions. These dimensions are: continuity, originality, reliability and naturalness. Another example is the scale developed by Napoli et al. (2014), that includes 14 items and integrates three main dimensions (factors) which are: quality commitment, sincerity and heritage.

When analyzing in the literature the case of experience and, in concrete, the construct of brand experience, one can also realize that several descriptions have also been used. For instance, brand experience has been characterized as "subjective, internal consumer responses (sensations, feelings, and cognitions) and behavioral responses evoked by brand-related stimuli that are part of a brand's design and identity, packaging, communications, and environments" (Brakus, Schmitt, \& Zarantonello, 2009, p. 53).

Within the context of hospitality and tourism, the concept of experience has also been addressed. In the study of Walls (2013), the author analyzes the antecedents of consumer experience and the outcome on consumers' perceived value, in a hotel setting. In the developed framework, two constructs have been used to explore consumers' perceived experiences: the physical environment (sights, tastes, sounds, textures, smells...) and the human interaction dimension (the behaviors of employees and customers involved in the service). In the specific case of this study, brand experience will be analyzed as an antecedent of brand authenticity.

The impact of brand experience on brand loyalty has been observed in different studies. For instance, Brakus et al. (2009) develop a brand experience scale based on four identified dimensions (sensory, affective, intellectual and behavioral) and state that brand experience affects directly consumer satisfaction and loyalty and, indirectly, through brand personality associations.

Loyalty has, in fact, been identified as an important outcome of several relevant marketing constructs, namely, brand experience. Brand loyalty has been described as "the biased (i.e., nonrandom), (2) behavioral response (i.e., purchase), (3) expressed over time, (4) by some decision-making unit, (5) with respect to one or more alternative brands out of a set of such brands, and (6) is a function of psychological (decision making, evaluative) processes" (Jacoby \& Kyner, 1973, p. 2). In hospitality studies, different measures have been commonly applied to evaluate loyalty. This is the case of repeat visitation, intention to return and recommendation to others (Manthiou, Kang, Sumarjan, \& Tang, 2016). In this study, brand loyalty will be analyzed as an outcome 
of both customer experience and brand authenticity.

Another construct that will be analyzed as a possible outcome of brand authenticity is brand coolness. Brands, to be considered cool by consumers, need to be "extraordinary, aesthetically appealing, energetic, high status, rebellious, original, authentic, subcultural, iconic, and popular" (Warren, Batra, Loureiro, \& Bagozzi, 2019, p. 36). In the study of Warren et al. (2019), the authors use grounded theory to understand what cool brands are and the main characteristics of these brands. Different tools have been applied like focus groups, depth interviews, essay writing, surveys, and experiments to develop a multi-item scale that could measure the brand coolness construct in different contexts.

Regarding methodology, this study will use a mixed methods approach, using both qualitative and quantitative methodologies. In the qualitative part, interviews with experts in the hospitality and tourism sectors will be held and this will enable us to understand how the constructs are perceived by practitioners, as well as the main dimensions associated to the constructs and the most relevant outcomes. A quantitative approach, based on the analysis of questionnaires, will be used to understand the perspective of customers. Understanding the opinions and the perceptions of both experts and consumers will be key to establish the associations among the different variables.

We do believe that this study will add value to theory as brand authenticity and customer experience are very important concepts in contemporary life and in marketing research. Therefore, studying them in the hospitality context will not only address relevant topics, but also answer to important knowledge gaps, already identified by scholars. We also think that this study will have relevant managerial implications as the consumers' quest for authenticity is a reality and having more insights about how brand authenticity is perceived by customers is very important for marketers and managers in general, to be able to differentiate their brands.

Keywords: brand authenticity, customer experience, hospitality.

\section{Acknowledgements}

We would like to acknowledge the financial support of Iscte- Instituto Universitário de Lisboa.

\section{References}

Beverland, M. B., \& Farrelly, F. J. (2010). The quest for authenticity in consu mption: consumers' purposive choice of authentic cues to shape experience d outcomes. Journal of Consumer Research, 36(5), 838-856. https://doi.org/ $10.1086 / 615047$

Brakus, J. J., Schmitt, B. H., \& Zarantonello, L. (2009). Brand Experience: W hat Is It? How Is It Measured? Does It Affect Loyalty? Journal of Marke ting, 73(3), 52-68. https://doi.org/10.1509/jmkg.73.3.52

Brown, S., Kozinets, R. V., \& Sherry, J. F. (2003). Teaching Old Brands New Tricks: Retro Branding and the Revival of Brand Meaning. Journal of $M$ arketing, 67(3), 19-33. https://doi.org/10.1509/jmkg.67.3.19.18657 
Bruhn, M., Schoenmüller, V., Schäfer, D., \& Heinrich, D. (2012). Brand authen ticity: Towards a deeper understanding of its conceptualization and measur ement. Advances in Consumer Research, 40, 567-576.

Dwivedi, A., \& McDonald, R. (2018). Building brand authenticity in fast-movi ng consumer goods via consumer perceptions of brand marketing communi cations. European Journal of Marketing, 52(7/8), 1387-1411. https://doi.org/ 10.1108/EJM-11-2016-0665

Fine, G. A. (2003). Crafting authenticity: The validation of identity in self-taug ht art. Theory and Society, 32(2), 153-180. https://doi.org/10.1023/A:10239 43503531

Fritz, K., Schoenmueller, V., \& Bruhn, M. (2017). Authenticity in branding - e xploring antecedents and consequences of brand authenticity. European Jou rnal of Marketing, 51(2), 324-348. https://doi.org/10.1108/EJM-10-2014-063 3

Gilmore, J. H., \& Pine, B. J. (2007). Authenticity: What consumers really wan t. Boston, MA: Harvard Business School Press.

Grayson, K., \& Martinec, R. (2004). Consumer Perceptions of Iconicity and In dexicality and Their Influence on Assessments of Authentic Market Offerin gs. Journal of Consumer Research, 31(2), 296-312. https://doi.org/10.1086/ 422109

Ilicic, J., \& Webster, C. M. (2014). Investigating consumer-brand relational aut henticity. Journal of Brand Management, 21(4), 342-363. https://doi.org/10. 1057/bm.2014.11

Jacoby, J., \& Kyner, D. B. (1973). Brand Loyalty Vs. Repeat Purchasing Beha vior. Journal of Marketing Research, 10, 1-9. https://doi.org/10.2307/31494 02

Lemon, K. N., \& Verhoef, P. C. (2016). Understanding Customer Experience T hroughout the Customer Journey. Journal of Marketing, 80(6), 69-96. http s://doi.org/10.1509/jm.15.0420

Manthiou, A., Kang, J., Hyun, S. S., \& Fu, X. X. (2018). The impact of bran $\mathrm{d}$ authenticity on building brand love: An investigation of impression in $\mathrm{m}$ emory and lifestyle-congruence. International Journal of Hospitality Manag ement, 75, 38-47. https://doi.org/10.1016/j.ijhm.2018.03.005

Manthiou, A., Kang, J., Sumarjan, N., \& Tang, L. R. (2016). The Incorporatio $\mathrm{n}$ of Consumer Experience into the Branding Process: An Investigation of Name-Brand Hotels. International Journal of Tourism Research, 18(2), 105 -115. https://doi.org/10.1002/jtr.2037

Mody, M., \& Hanks, L. (2019). Consumption Authenticity in the Accommodati ons Industry: The Keys to Brand Love and Brand Loyalty for Hotels and Airbnb. Journal of Travel Research. https://doi.org/10.1177/00472875198262 33

Morhart, F., Malär, L., Guèvremont, A., Girardin, F., \& Grohmann, B. (2015). Brand Authenticity: An Integrative Framework and Measurement Scale. Jo urnal of Consumer Psychology, 25(2), 200-218. https://doi.org/10.1016/j.jcp s.2014.11.006

Moulard, J. G., Raggio, R. D., \& Folse, J. A. G. (2016). Brand Authenticity: Testing the Antecedents and Outcomes of Brand Management's Passion for its Products. Psychology \& Marketing, 33(6), 421-436. https://doi.org/10.1 002/mar.20888

Napoli, J., Dickinson-Delaporte, S., \& Beverland, M. B. (2016). The brand aut 
henticity continuum: strategic approaches for building value. Journal of $M a$ rketing Management, 32(13-14), 1201-1229. https://doi.org/10.1080/0267257 X.2016.1145722

Napoli, J., Dickinson, S. J., Beverland, M. B., \& Farrelly, F. (2014). Measurin g consumer-based brand authenticity. Journal of Business Research, 67(6), 1090-1098. https://doi.org/10.1016/j.jbusres.2013.06.001

Pine, B. J., \& Gilmore, J. H. (1998). Welcome to the experience economy. $\mathrm{Ha}$ rvard Business Review, 76(4), 97-105.

Spiggle, S., Nguyen, H. T., \& Caravella, M. (2012). More than Fit: Brand Ext ension Authenticity. Journal of Marketing Research, 49(6), 967-983. https:/ /doi.org/10.1509/jmr.11.0015

Walls, A. R. (2013). A cross-sectional examination of hotel consumer experienc e and relative effects on consumer values. International Journal of Hospita lity Management, 32, 179-192. https://doi.org/10.1016/j.ijhm.2012.04.009

Warren, C., Batra, R., Loureiro, S. M. C., \& Bagozzi, R. P. (2019). Brand Co olness. Journal of Marketing, 83(5), 36-56. https://doi.org/10.1177/0022242 919857698 